\title{
楉導入型ポリアリルアミンのホウ素吸着特性
}

\author{
甲斐田寒彦* 犬養吉成, 安田誠二* 山下武広** \\ 迎 勝 也*** 境 正志*** 湾 留 壽 昭***
}

\section{Adsorption Properties of Boron on Branched-Saccharide-Polyallylamine Resins}

\author{
Yasuhilko KAIDA *, Yoshinari INUKAI *, Seiji YASUDA *, Takehiro YAMASHITA ** \\ Katsuya MUKAE ***, Masashi SAKAI ***, and Toshiaki TSURU ***
}

* National Institute of Advanced Industrial Science and Technology, Kyushu, 807-1 Shuku-machi, Tosu-shi, Saga 841-0052, Japan

* Asahi Pretec Corp., 21 Uozakihama-machi, Higashinada-ku, Kobe-shi, Hyogo 658-0024, Japan

*** Department of Industrial Chemistry, Kyushu Sangyo University, 2-3-1 Matsukadai, Fukuoka-shi, Fukuoka 8138503, Japan

\begin{abstract}
A boron adsorption material for treating wastewater containing boron was synthesized from various types of saccharides and a polyallylamine resin. The adsorption properties of boron were investigated by the batch and column methods using model wastewater. In the synthetic reaction for the $D(t)$-mannose-type polyallylamine resin, the optimum mole ratio of $D(t)$ - mannose to one unit of polyallylamine was 1.0. Furthermore, the optimum reaction time and temperature of the synthetic reaction were found to be 24 hours and $35^{\circ} \mathrm{C}$, respectively. The amount of boron adsorbed on the $\mathrm{D}(t)$-mannose-type polyallylamine resin exceeded $0.5 \mathrm{mM} \cdot \mathrm{g}^{-1}$ in the $\mathrm{pH}$ range of $2-12$, and boron could be effectively adsorb onto the $D(t)$-mannose-type polyallylamine resin from model wastewater. At the optimum $\mathrm{pH}$ of 8.5 , the maximum quantity of boron adsorbed was $2.06 \mathrm{mM} \cdot \mathrm{g}^{-1}$. The adsorption isotherm of boron on the $D(t)$-mannose-type polyallylamine resin follows Freundlich's equation in the equilibrium concentration range from $0.045 \mathrm{mM} \cdot l^{-1}$ to $15.0 \mathrm{mM} \cdot l^{-1}$ at $25^{\circ} \mathrm{C}$. When a feed solution containing $2.0 \mathrm{mM} \cdot l^{-1}$ boron was pumped into the $\mathrm{D}(t)$-mannose-type polyallylamine resin column, the volume of effluent containing less than $0.02 \mathrm{mM} \cdot l^{-1}$ boron was about 311 times the bed volume, which was about 3.3 times the column of Amberlite IRA-743. The boron that was adsorbed on the $D(t)$-mannose-type polyallylamine resin column was easily eluted with a $1.0 \mathrm{M} \cdot l^{-1}$ hydrochloric acid solution, and the elution ratio was $100.6 \%$ of the adsorbed boron on the column.
\end{abstract}

Key words : $D(t)$-mannose-type polyallylamine resin, saccharide, boron, adsoption properties, wastewater

\section{1.はじタに}

ポリアリルアミンは側鎖に第1アミノ基を有主るカチォン系 高分子であり，第1アミノ基の高い反応性を利用した各種誘 導体の母材としても有用である ${ }^{1-4)}$ 。ポリアリルアミンを架橋処 理して得られた粒状の高分子樹脂は高い陰イオン交換能を 有するため有害半金属のオキソ酸隍イオンの吸着材として 優れているが，ホウ素等一部の有害半金属はほとんど吸着 しない"5)。他方，ホウ素は有害半金属として平成11年2月に 水質污濁に係る環境基準項目に追加され，平成13年7月 には排水基淮項目に加えられており，3年後の暂定基準の 見直しや上乘せ基準の導入も予想されることから，事業所等 の木ウ素含有廃水処理が急務となっている。ホウ素は耐熱。 液晶ガラスをはじめ，触媒，橎薬，殺虫剤等幅広く利用さ れ，ほぼ全量を外国からの輸入に依存している。年間輸入
量はホウ酸，ホウ砂合わせて7.9万トン(2000)に達しており， 究極的には回収して再利用が望まれる貴重な資源である゙。

以上の観点加筆者等は，有害半金属含有廃水の処理 を目的として，新しいホウ秦吸着材の開発および高品位の ホウ素の回収が見込まれる吸脱着処理システムの開発につ いて険討它行っている年10)。今回，ポリアリルアミンに各種糖 類を導入した糖型ポリアリルアミンによるホウ素の吸着挙動 について検討を行い，特にD(t)-マンノース型ポリアリルアミン 吸着材の合成法および同吸着材のホウ素に対する吸着特 性を検討した結果について述べる。

\section{2. 方 洷}

2.10 (†ーマンノース型ポリアリルアミンの合成

听マンノース型ポリアリルアミンの合成法を聠.1 に示す。 
<smiles>CCC(C)C(C)CC</smiles>

$$
+
$$

$\mathrm{C}_{6} \mathrm{H}_{12} \mathrm{O}_{6}$
$D(+)$-mannose

Polyallylamine

$\left(\mathrm{CH}_{3}\right)_{2} \mathrm{NH} \cdot \mathrm{BH}_{3}$ Dimethylamine-borane $-\mathrm{H}_{2} \mathrm{O}$<smiles>CCC(C)C(C)C</smiles>

$\mathrm{CH}_{2}-(\mathrm{CHOH})_{4}-\mathrm{CH}_{2} \mathrm{OH}$

$D(t)$-mannose-type polyallylamine

Fig.1 Synthesis of branched $1(t)$-mannose-type polyallylamine

合成反応はジメチルアミンボランを用いる還元的アルキル化 反応によった。合成手順は以下の通りである。ポリアリルア ミン塩酸塩粒状物 (PAA-B: 日東紡續社製，極微粒分を傾斜 洗浄除去したもの，粒径:約 $0.21 \sim 0.45 \mathrm{~mm} １ .0 \mathrm{~g}$ \% $100 \mathrm{ml}$ 容三角フラスコに分取し, 適量の純水を加えて膨潤後, あら かじめ純水に溶解した口(+)-マンノ一スを加えて全容積を $20 \mathrm{ml}$ とし, ジメチルアミンボランを直接添加した後, 恒温水槽内 で振とうして合成した。得られたD(t)-マンノ一ス型ポリアリルアミ ンはジメチルアミンボラン由来のホウ素を $1.0 \mathrm{~mol} \cdot l^{1}$ 塩酸で洗 浄除去した後, 純水拉よびメタノールで洗浄し, 室温で減圧 乾燥して暗所保存した。吸着材のD(t)-マンノース導入率は元 素分析值のC/N值より算出した。また，比較のためD(-)アラビ ノース型ポリアリルアミン等の8種類の糖型ポりアリルアミンに ついも同様の方法により合成した。合成実験に供した試薬 はジメチルアミンボランなどー部の試薬を除いていずれも市 販特級試楽を使用した。元素分析計はパーキンエルマー社 製CHNS/O Analyzer 2400型を使用した。

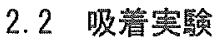

吸着実験に供したホウ素溶液はホウ酸の $100 \mathrm{mmol} \cdot l^{-1}$ 原液 を適宜希秎して調製した。バッチ昅着実験は， $50 \mathrm{ml}$ 容三角 フラスコに所定濃度のホウ素溶液 $25 \mathrm{~m} l$ を入れ, 所定量の吸 着材を精秤して加え，希水酸化ナトリウム溶液または希塩酸 を用いてpHを調整した後，恒温水槽内で所定時間振とうし て吸着させた。力ラム吸着実験は，室温下，下降流式で行 った。内径 $5 \mathrm{~mm}$ ，管長 $100 \mathrm{~mm}$ のガラス製力ラムに所定量の吸 着材を充填し，ペリスタ型ポンプを用いてホウ素溶液を送入 し，処理液をフラクションコレクターで分画採取した。カラム 吸着実験のホウ素莀度は排水基準值の約 2 倍の $2.0 \mathrm{mmol} \cdot l^{-1}$ とし，吸着寡のpHを一定に保つために0.1mol· $l^{-1}$ 塩化アンモ ニウムーアンモニア緩衝液を用いた。バッチおよびカラム吸 着実験にはD(t)-マンノ一ス型ポリアリルアミンのほか, 各種䌅 型ポリアリルアミン，および市肘吸着材の中から既報りにより 優れたホウ素吸着のpH依存性および吸着等温線を示したメ チルグルカミン系ホウ素吸着材のアンバーライトRA-743(粒 径: 0.39 0.49 mm), ならびにポりアミン系陰イオン交換樹 脂アンバーライトIRA-60E (粒径: $0.36 \sim 0.46 \mathrm{~mm}$ ) 等の各塩 酸塩型を使用した。供試薬はいずれも市販特級相当品を用 いた。 $\mathrm{pH}$ 測定は東亜ディーターター社製HM-5Sを使用し た。ホウ素の分析はセイコーインスツルメント社製ICP分析装 置SPS-1200AR型を使用した。

\section{3.实驗結䱊および考察}

\section{$3.10(t)-マ ン ノ ー ス$ 型ポリアリルアミンの合成 3.1.1D(十ーマンノース添加置の影響}

D(t)-マンノース型ポリアリルアミンの合成におよぼすD(t)マン ノ一スの添加量の影響について検討した。ポリアリルアミン1 単位に対する埕-マンノースの添加てル比を $0.25 \sim 1.5$ と変え, 温度 $30^{\circ} \mathrm{C} ， 24$ 時間で合成したときのD $(t)$-マンノース導入率を Fig.2 に示方。図より，D(t)-マンノースモル比0.25においてD(t)マンノース導入率は26.8\%であったが，同モル比1.0におい ては66.5\%に達した。财-マンノースモル比1.0〜1.5において は，同モル比と共にD(t)-マンノース導入率がわずかに高くなる 傾向が認められたが，同モル比1.5に㧍けるD(けマンノース導 入率は68.1\% \%であり，ほぼ一定の值を示した。以上より，D(t) マンノースの最適添加量はポリアリルアミン1単位に刘してモ ル比 1.0 相当であると考えられる。

\section{1 .2 ジメチルアミンボラン添加甼の影響}

還元戍のジメチルアミンボランの最適添加量を調べるた め, ポリアリルアミン1単位に対するジメチルアミンボランの添 加モル比を0.25〜2.0と変え, 温度 $30^{\circ} \mathrm{C} ， 24$ 時間で合成した 結果を Fig.3 に示す。図より，D(t)-マンノース導入信は，ジメ チルアミンボランモル比1.0において，66.5\%上最も高くなる ことがわかる。ジメチルアミンボランを等モル以上に添加する と逆にD(t)-マンノース導入率は低下し，同モル比2.0において

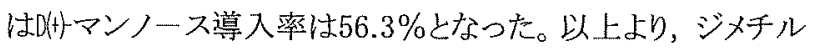
アミンボランの添加量はポリアリルアミンの1単位に対して等 モル量が最適であり，過剩量の添加は極力避ける必要があ ることがわかった。

\section{1 .3 反応時䦗の影艟}

D(†)マンノース型ポリアリルアミンの合成におよぼす反応時 間の影響を調べた。ポリアリルアミン1単位に対して等モル量 のD(t)-マンノースおよびジメチルアミンボランを加え, 温度 30

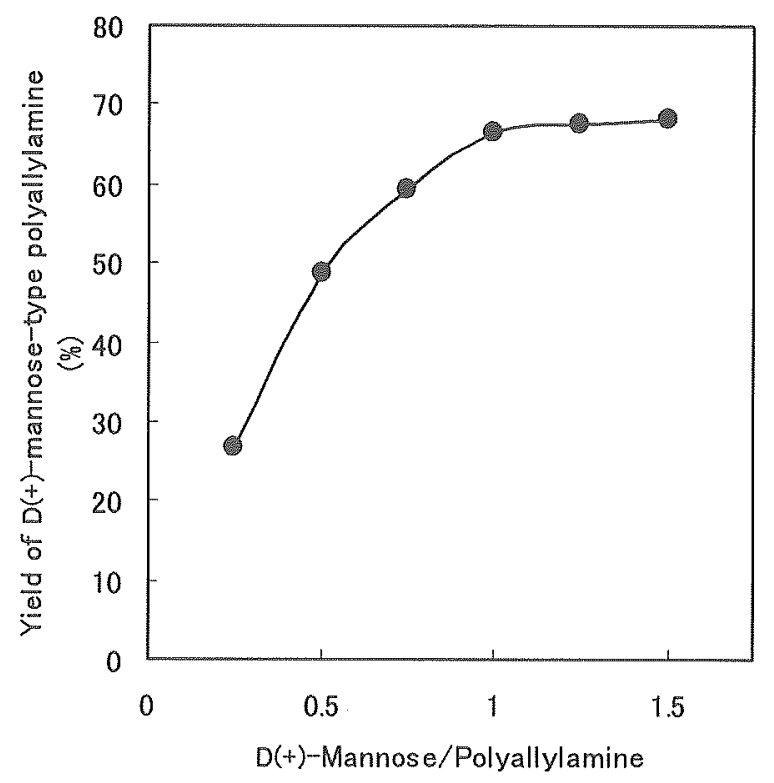

Fig.2 Effect of the amount of the $D(t)$-mannose on the yield point of the $D(t)$-mannose-type polyallylamine resin at $30{ }^{\circ} \mathrm{C}$.

Feed mole ratio of dimethylamine-borane/polyallylamine $=1.0$, Shaking time: $24 \mathrm{hr}$ 
${ }^{\circ} \mathrm{C}$ で合成したときの反応時間と $(t)$-マンノース導入率の関係

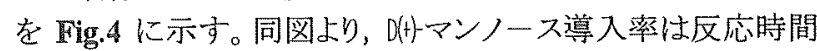
と共に高くなり，24時間で約 $66.5 \%$ に達し，以後ほぼ一定と なった。このことより，D(t)-マンノ一ス型ポリアリルアミンの合成 における最適反応時間は24時間と考えられる。本実験にお いては，次の温度の効果も考慮して反応時間は24時間とし to

\section{1 .4 反応温黁の影響}

次に, D(t)-マンノース型ポリアリルアミンの合成におよぼす 反応温度の影罀を調べた。ポリアリルアミン1単位に対して 等モル量のD(t)-マンノースおよびジメチルアミンボランを加え， 24時間振とう合成したときの反応温度とD(けマンノース導入率 の関係を Fig.5 に示した。同図より，反忘温度 $20^{\circ} \mathrm{Ckおいて}$

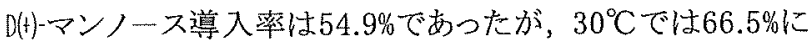
達し,さらに $35^{\circ} \mathrm{C}$ 以上では68.4〜 69.8\%とほぼ一定になること がわかったこのことから，最適反応温度は $35^{\circ} \mathrm{C}$ 考えられ， D(t)-マンノース型ポリアリルアミンの合成におよぼす温度の影 響は極めて顕著であることがわかった。同図において，反応 1 時間後の什マンノース導入率は，温度 $50^{\circ} \mathrm{C}$ おび $60^{\circ} \mathrm{CK}$ おいて各々 $54.4 \%$ および $57.7 \%$ に達することから, 温度 $50^{\circ} \mathrm{C}$ 以上において短時間で合成する方法も有効上考えられる。 しかしながら，反応温度 $20 \sim 40^{\circ} \mathrm{C} て ゙$ 得られた吸着材が白色 または白黄色を帯びたものであるのに対して，温度50 C以 上で得られた吸着材は黄色が濃くなる傾向を示した。このよ うな外観上の変化は，水一メ夕ノ一ル(1:1)混合溶媒を用い て温度 $50^{\circ} \mathrm{C}$ 以上で合成した場合にも明暸に観察され，得ら れた吸着材は元素分析值のC/ $\mathrm{N}$ 值が高く, D(t)-マンノース導 入率は75.6\%と高い值を示したが，ホウ素吸着量は予想に反 して著しく低い值を示した。母材のポリアリルアミンは奴ー ルに対して易可溶性であることから，温度効果も相まって母 材または吸着材が化学的変成を受けた可能性を示唆してい る。温度の影響については，C/N值より算出したD(t)ママンノー

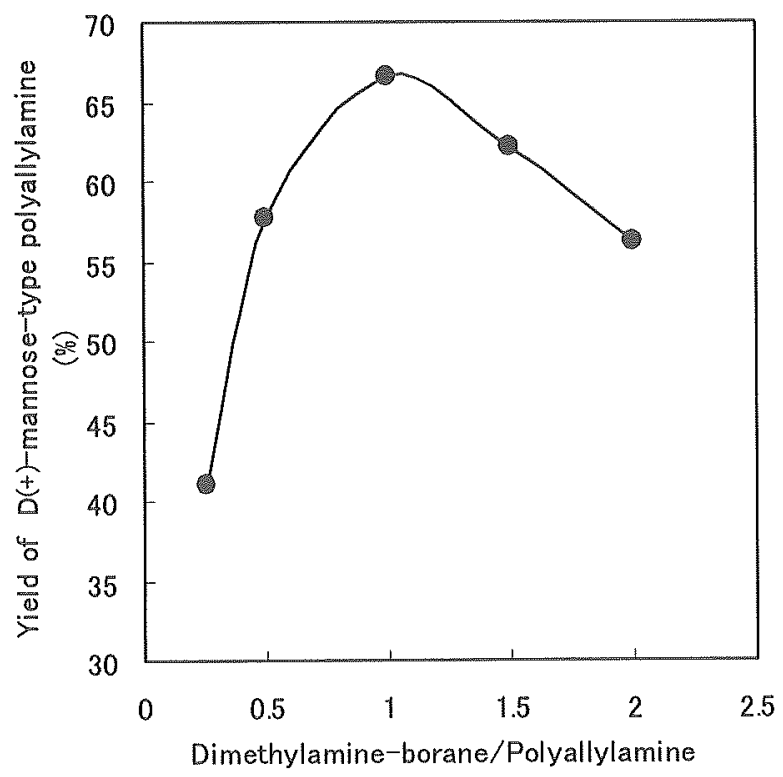

Fig.3 Effect of the amount of the dimethylamine-borane on the yield point of the $D(t)$-mannose-type polyallylamine resin at $30^{\circ} \mathrm{C}$.

Feed mole ratio of $D(t)$-mannose/polyallylamine $=1.0$ Shaking time: $24 \mathrm{hr}$
ス導入率による評価ではなく，直接的にホウ素の吸着量を 求めて検討する必要がある。

以上の結果をもとに，D(t)-マンノースおよびジメチルアミン ボランはポリアリルアミン 1 単位に対して各々等モル量を加 え，温度は比較的稳和な条件 $930^{\circ} \mathrm{C}$ と，反応時間 24 時間 で合成した吸着材を以下のホウ素吸着実験に供した。得ら れたD(けマンノース型ポリアリルアミンはわずかに黄白色を帯

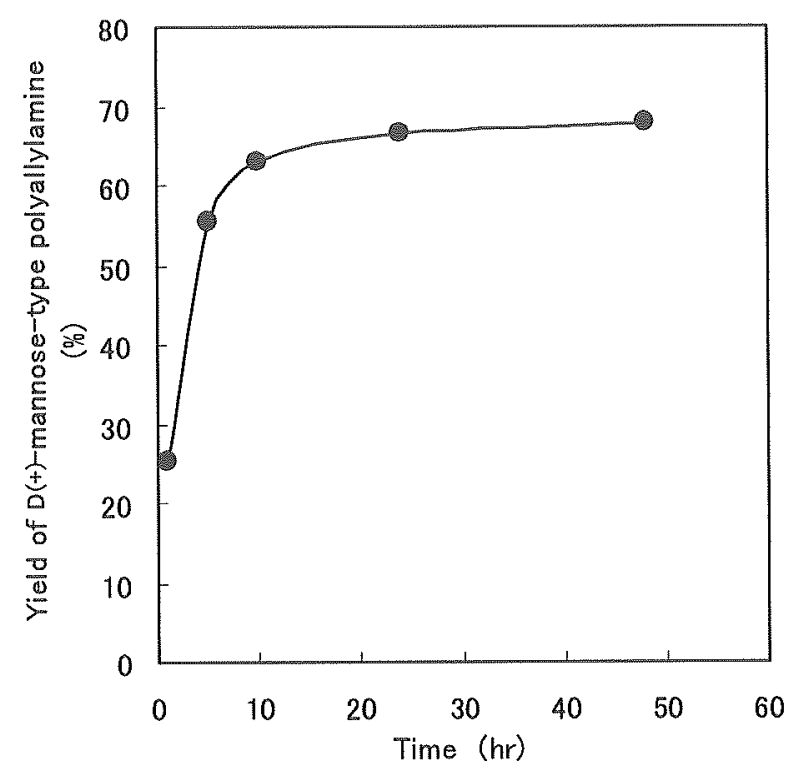

Fig.4 Effect of the shaking time on the yield point of the D $(t)$-mannose-type polyallylamine resin at $30{ }^{\circ} \mathrm{C}$.

Feed mole ratio of $D(t)$-mannose / polyallylamine $=1.0$ Feed mole ratio of dimethylamine-borane/ polyallylamine $=1.0$

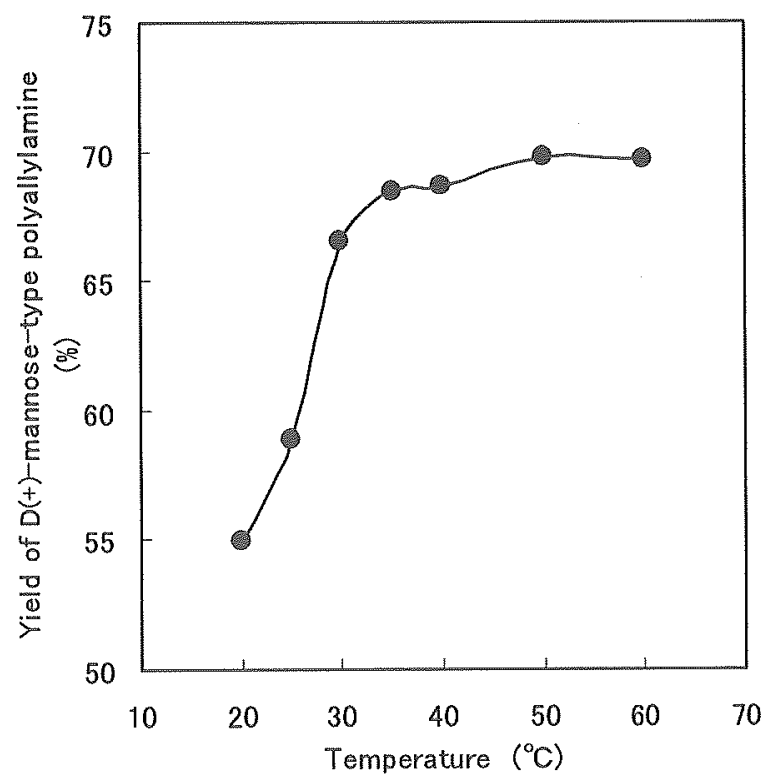

Fig.5 Effect of the temperature on the yield point of the $D(t)$ mannose-type polyallylamine resin.

Feed mole ratio of $D(t)$-mannose/polyallylamine $=1.0$

Feed mole ratio of dimethylamine-borane / polyallylamine $=1.0$, Shaking time: $24 \mathrm{hr}$ 
びた吸湿性の粒状物であり，元素分析值より算出したD(t)-マ ンノース導入率は66.2\%であった。

\section{2 ホウ寗のバッチ吸着処理}

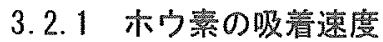

ホウ素 $10 \mathrm{mmol} \cdot l^{-1}$ 和よび塩化力リウム $0.1 \mathrm{~mol} \cdot l^{-1}$ の溶液 $25 \mathrm{~m} l$ にD(t)-マンノース型ポリアリルアミン $0.05 \mathrm{~g}$ 添加し, 温度 $25^{\circ} \mathrm{C}$ で吸着させた時のホウ素吸着量の経時変化を Fig.6 に示 す。同図には比較のために，母材のポリアリルアミンおよび アンバーライトIRA-7430测定結果も示してある。図より，D(t) ーマンノース型ポリアリルアミンの場合，ホウ素吸着量は時間 と共に増大し, 約5時間で吸着平衡に到達すると共に，吸着 量は2.05 mmol· $\mathrm{g}^{-1}$-dryに達した。アンバーライトIRA-743は吸 着平衡時の吸着量は $0.66 \mathrm{mmol} \cdot \mathrm{g}^{-1}-\mathrm{dry}$ と低いが，ほぼ類似 の傾向を示した。D(t)ンノース型ポリアリルアミンによるホウ 素の吸着はO原子を配位原子する錯体の形成に起因方ると

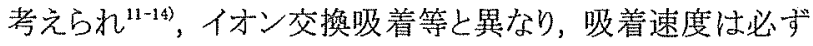
しも速くない。叶マンノース導入率が低い吸着材についても 同様に吸着時間とホウ素吸着量の関係を調心゙た結果，D(f)-マ ンノース導入率 $48.6 \%$ の場合，わずかに吸着曲線の立ち上 がりは早いが，吸着平衡時間は約5時間とほとんど差がなか った。以後の実験においては，吸着時間は24時間とした。

\section{2 .2 木门害吸着のpH依存憆}

ホウ素 $2.0 \mathrm{mmol} \cdot l^{-1}$ および塩化力リウム $0.1 \mathrm{~mol} \cdot l^{-1}$ の溶液 $25 \mathrm{~m}$ $l$ にD(t)-マンノース型ポリアリルアミン0.03gを添加し，ホウ素 吸着のpH依存性を調べた。結果を Fig.7 に示す。図より, p H2からpH9.00範囲ではpHが高くなるにつれてホウ素吸着 量が高くなり，pH9.5以上では，ポリアリルアミンの第1アミン 残基が遊離化して吸着材全体が強く瑓水性を帯びるためホ ウ素吸着䑁は急激に低下し, pH12.5以上ではほとんど吸着 しなくなった。ホウ酸の酸解離定数pKは(1)式において9.1

$$
\mathrm{B}(\mathrm{OH})_{3}+\mathrm{H}_{2} \mathrm{O} \rightleftharpoons \mathrm{B}(\mathrm{OH})_{4}{ }^{-}+\mathrm{H}^{+}
$$

であるが(イオン強度 $\left.\mu=0.1 \mathrm{~mol} \cdot l^{-1}\right)$ ， Fig.7 に○印で示した ホウ酸のオキソ酸陰イオンの分布曲線からも明らかなように, pH9以下の中性および弱酸性領域では主としてオキソ酸イ オンとして，他方 $\mathrm{pH}$ 月以上の弱アルカリ性領域においては主 としてオキソ酸陰イオンとして吸着除去されているものと考え られる。なお，塩化力リウム非共存下では，ポリアリルアミン の第1アミン残基に吸着した塩素イオンがホウ素の吸着に伴 って溶離することから，ホウ素の吸着には，第一アミノ基によ る陰イオン交換も寄与している可能性が示唆された。

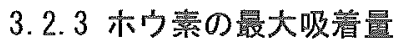

D(t)マンノース型ポリアリルアミン以下，9種類の喏型ポリア リルアミン，ポリアリルアミン，アンバーライトIRA-743执よび アンバーライトIRA-60Eによるホウ素の最大吸着量について 検討した。ホウ素 $10 \mathrm{mmol} \cdot l^{-1}$ および塩化力リウム $0.1 \mathrm{~mol} \cdot l^{-1}$ の 溶液 $25 \mathrm{ml}$ に吸着材 $0.05 \mathrm{~g}$ を加え，温度 $25^{\circ} \mathrm{C}, 24$ 時間で吸着 実験を行った時の最大吸着量をTable 1 に示した。表より， ホウ素の最大吸着量はポリアリルアミンに導入された喏鎖の 種類によって暴なり，へキソースのD(t)マンノース，D(t)グルコー

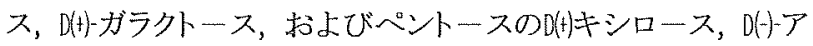
ラビノースの各糖型ポリアリルアミンは $2 \mathrm{mmol} \cdot \mathrm{g}^{-1}-\mathrm{dry}$ 前後の ホウ素吸着量を示し，特にD(-ケラビノースおよびD(t)ガラクト 一ス型の各ポリアリルアミンは各々 $2.34 \mathrm{mmol} \cdot \mathrm{g}^{-1}-\mathrm{dry}$ ，および $2.23 \mathrm{mmol} \cdot \mathrm{g}^{-1}$-dry上高い吸着量を示した。D(t) マンンース型ポ

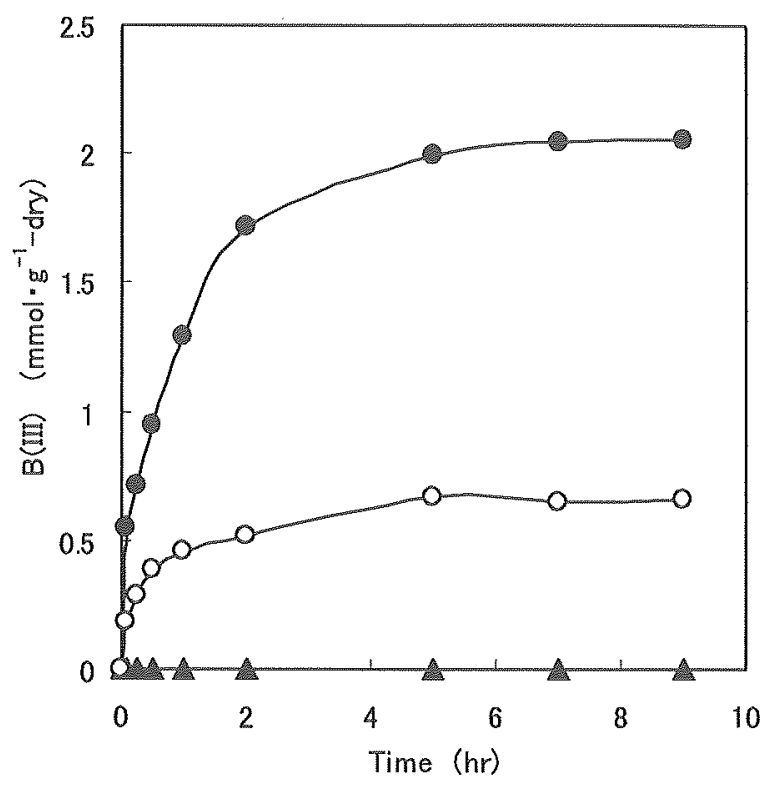

Fig.6 Effect of the shaking time on the adsorption of boron on the $D(t)$-mannose-type polyallylamine resin at $25^{\circ} \mathrm{C}$. :D(t)-mannose-type polyallylamine O:Amberlite IRA743

:Polyallylamine

Boron: $10 \mathrm{mmol} \cdot l^{-1}, \mathrm{KCl}: 0.1 \mathrm{~mol} \cdot l^{-1}$

pH8.43 8.51, Resin:0.05g, Shaking time:24hr

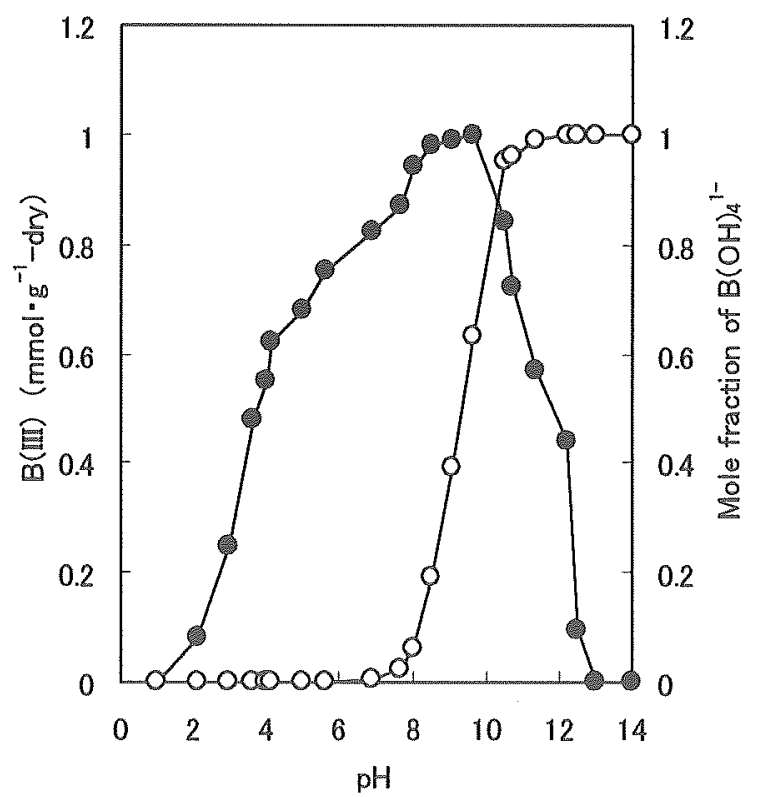

Fig.7 Effect of $\mathrm{pH}$ on the adsorption of boron on the $D(+)$ - mannose-type polyallylamine resin at $25^{\circ} \mathrm{C}$.

:D(†)-mannose-type polyallylamine $\mathrm{O}: \mathrm{B}(\mathrm{OH})_{4}{ }^{\prime}$

Boron: $2.0 \mathrm{mmol} \cdot l^{-1}, \mathrm{KCl}: 0.1 \mathrm{~mol} \cdot l^{-1}$ Resin:0.03g, Shaking time: $24 \mathrm{hr}$

リアリルアミンの最大吸着量は $2.06 \mathrm{mmol} \cdot \mathrm{g}^{-1}-\mathrm{dry}$ であり，粒径 が異なるので直接的比較は困難であるが，メチルグルカミン 系ホウ素吸着材のアンバーライトIRA-743の約3.6倍であっ 
Table 1 Adsorption capacity of saccharide-type polyallylamine resin for boron at $25^{\circ} \mathrm{C}$.

\begin{tabular}{|l|c|}
\hline \multicolumn{1}{|c|}{ Saccharide } & $\begin{array}{c}\mathrm{B} \\
\left(\mathrm{mmol} \cdot \mathrm{g}^{-1} \text {-dry }\right)\end{array}$ \\
\hline D(t)-Mannose & 2.06 \\
D(t)-Glucose & 2.02 \\
D(t)-Galactose & 2.23 \\
L(t)-Rhamnose & 1.59 \\
D(t)-Xylose & 1.93 \\
D(-)-Arabinose & 2.34 \\
D(t)-Lactose & 1.46 \\
D(t)-Maltose & 1.03 \\
D(t)-Galacturonic acid & 1.25 \\
\hline Amberlite IRA-743 & 0.58 \\
Polyallylamine & 0.13 \\
Amberlite IRA-60E & 0.05 \\
\hline
\end{tabular}

Boron: $10 \mathrm{mmol} \cdot l^{-1}, \mathrm{KCl}: 0.1 \mathrm{mmol} \cdot l^{-1}$

Resin:0.05g, pH:7.78 8.82, Shaking: $24 \mathrm{hr}$

た。糖鎖の末端にメチル基を有する妖ルペントースのい(け) ムノース型ポリアリルアミンや二糖類型ポリアリルアミンはへ キソースおよびペントース型ポリアリルアミンより若干低い吸 着量を示した。このようなホウ菜最大吸着量の差異は, 同一 の合成条件下に执いて糖鎖導入率が矹の種類によって各 々異なることが主因の一つと考えられ，例えば，二䌅類の奻 一マルトースの場合, 導入率が26.3\%と低いためにホウ素の最 大吸着量が低いものと考えられる。しかし，D(t)ガラタトースの 遵入率は57.1\%と低いにもかかわらずホウ素最大吸着量はD如 ーマンノースよりも高いといら結果も得られており，糖鎖とホウ 素吸着量の関係は必ずしも明瞭ではない。なお，母材のポ リアリルアミンおよびポリアミン型陰イオン交換材のアンバー ライトIRA-60Eは吸着量が低いかまたはほとんど吸着しない ことがわかった。

\section{2 .4 ホウ害の吸新筑温線}

ホウ素0.5 20.0 $\mathrm{mmol} \cdot l^{-1}$ および塩化力リウム $0.1 \mathrm{~mol} \cdot l^{-1} の$ 溶液 $25 \mathrm{ml}$ にD(t)-マンノース型ポリアリルアミン $0.1 \mathrm{~g}$ を添加し, 温度 $25^{\circ} \mathrm{C} ， 24$ 時間で吸着実験を行った。吸着平衡時の液相 中のホウ素濃度と吸着量を测定し, Freundlich型吸着実験 式を用いて吸着等温線を求めた。結果を Fig.8 に示す。同 図より，測定值に多少のばらつきはあるが，ホウ素の吸着平 衡濃度 $0.0446 \sim 15 \mathrm{mmol} \cdot I^{1}$ の範囲で比較的良好な直線関係 が得られ，次の実験式(2)が得られた。

$$
x \cdot m^{-1}=0.904 \cdot C^{0.37}
$$

ここで, $x$ はホウ素吸着量 $\left(\mathrm{mmol} \cdot \mathrm{g}^{-1}\right), m$ は吸着材重量 $(\mathrm{g}) ， C$ はウ素吸着平衡濃度 $\left(\mathrm{mmol} \cdot l^{-1}\right)$ である。

以上より，D(t)マンノース型ポリアリルアミンによるホウ素の 吸着はFreundlich型吸着であり，樹脂内部への吸収もホウ 素吸着に奇与していることが示唆された。また，平衡濃度 15 mmol· $l^{-1}$ におけるホウ素吸着量は $2.50 \mathrm{mmol} \cdot \mathrm{g}^{-1}-\mathrm{dry}$ に達し to

\section{3 ホウ畒の力ラム吸谙処理}

\subsection{1 ホウ索の破過曲線}

D(t)マンノ一ス型ポリアリルアミン, アンバーライトIRA-743 およびポリアリルアミンによるホウ素の動的吸着特性を明らか

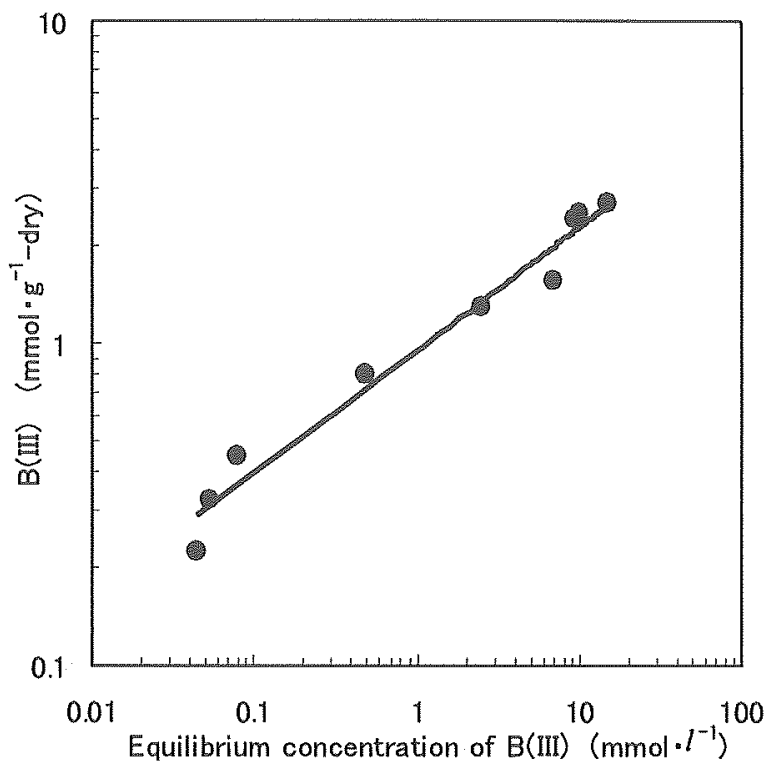

Fig.8 Adsorption isotherm for boron on the $D(t)$-mannose type polyallylamine resin at $25^{\circ} \mathrm{C}$.

Boron:0.5 20 $\mathrm{mmol} \cdot l^{-1}, \mathrm{KCl}: 0.1 \mathrm{~mol} \cdot l^{-1}$

$\mathrm{pH}: 8.20 \sim 8.55$, Resin:0.1g, Shaking:24hr

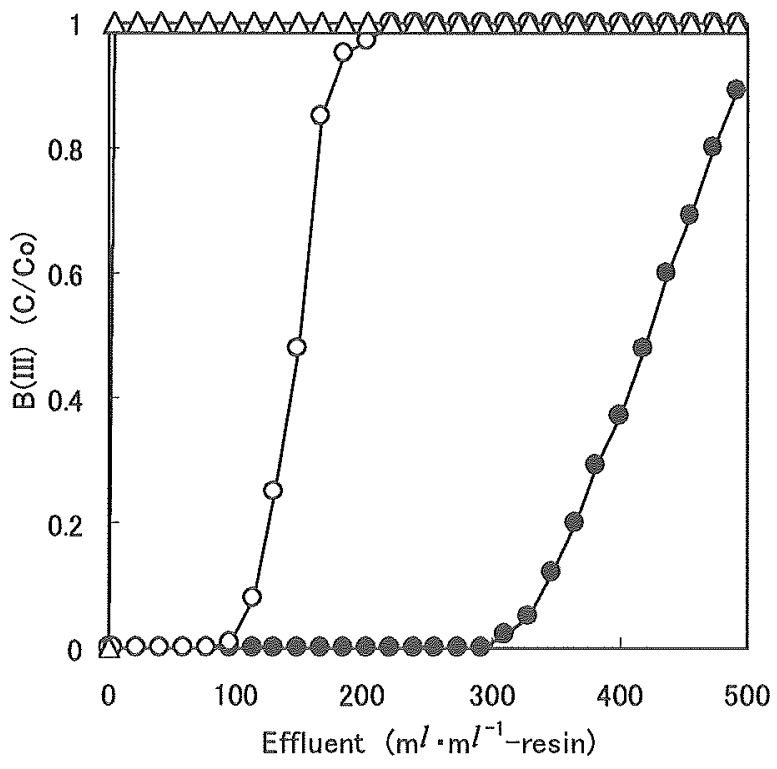

Fig.9 Breakthrough curves for boron on the $D(t)$-mannose type polyallylamine resin and $\mathrm{N}$-methylglucamine type resin at room temperature.

:D(t)-mannose-type polyallylamine $(0.21-0.45 \mathrm{~mm})$

O:Amberlite IRA743 (0.39-0.49 mm)

$\triangle$ :Polyallyl-amine $(0.21-0.45 \mathrm{~mm})$

Boron: $2.0 \mathrm{mmol} \cdot l^{-1}, 0.1 \mathrm{~mol} \cdot l^{-1} \mathrm{NH}_{4} \mathrm{Cl}-\mathrm{NH}_{4} \mathrm{OH}$

Resin: $1.50 \sim 1.80 \mathrm{ml}, \mathrm{pH}: 8.5$

にするため、各吸着材 $1.50 \sim 1.80 \mathrm{ml}$ を充填した力ラムに，木 ウ素 $2.0 \mathrm{mmol} \cdot l^{-1}$ 溶液をSV(Space Velocity $\left.{ }^{16}\right) 5.0 \mathrm{~h}^{-1}$ で通 液してカラム吸着実験を行った。ホウ素溶液のpHは(A)-マン) 一ス型ポりアリルアミンカラムと同様に, アンバーライトRA-7 43力ラムの場合も予備実験の結果および既報”に基ついて 


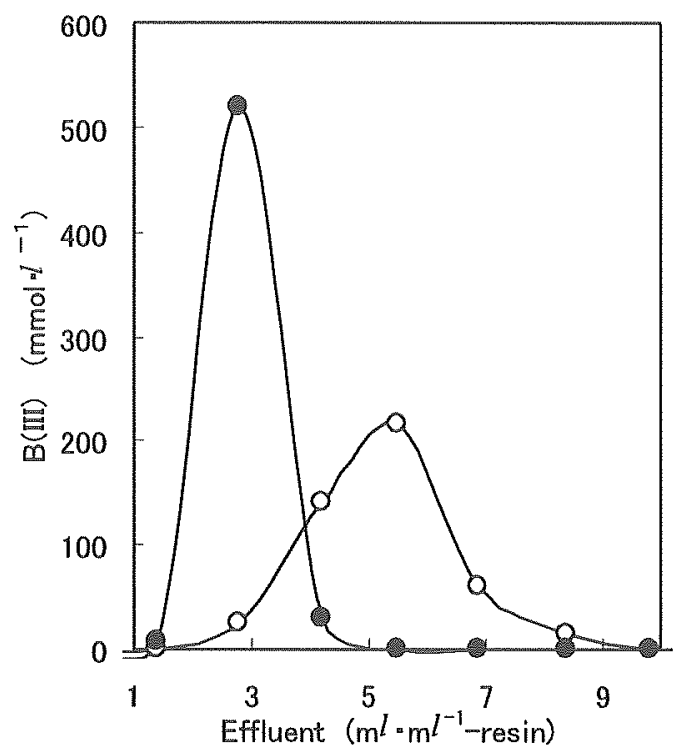

Fig.10 Elution curves for boron on $D(t)$-mannose-type polyallylamine resin at room temperature.

: $\mathrm{HCl}: 1.0 \mathrm{~mol} \cdot l^{-1}, \mathrm{SV}: 5.0 \mathrm{~h}^{-1}$ O:HCl:0.1 mol $\cdot l^{-1}, \mathrm{SV}: 10 \mathrm{~h}^{-1}$

最適值の8.5に調節した。処理液量を吸着材容積で除した 通液倍数と処理液中の木ウ素濃度加吸脱着7回目の破過 曲線を求めて Fig.9 に示した。(t)-マンノース型ポリアリルアミ ンカラムの破過点 $(\mathrm{C} / \mathrm{Co}=0.01)$ における通液倍数は 311 であ り、アンバーライトRA743カラムの95より3.3倍高いことがわか った。

\subsection{2 カラムの再生}

ホウ素を吸着したD(+-マンノース型ポリアリルアミンカラムの 溶離再生について検討した。上述の吸着実験に供したカラ

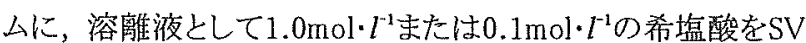
$5.0 \mathrm{~h}^{-1}$ または $10 \mathrm{~h}^{-1} て ゙$ 通液したときの溶離液中の木ウ素を分析 し, 溶離曲線を求めて Fig.10 に示した。D(t)-マンノース型ポリ アリルアミンカラムの溶離再生に $1.0 \mathrm{~mol} \cdot l^{1}$ 希塩酸を用いた結 果,7回目の吸脱着において，吸着材容積の約5倍量を通 液したときのホウ素溶離率は100.6\%であり，ホウ素の濃縮比 は最高275倍に達した。また, $0.1 \mathrm{~mol} \cdot l^{-1}$ 希塩酸の場合,吸着 材容積の約10倍量でホウ素の溶離率は98.5\%であり，SVが $10 \mathrm{~h}^{-1}$ と高いことも相まって，溶離曲線がブロードになり，濃縮 比は108倍と低い值を示した。

\section{4. 緢諭}

ホウ素吸着材の開発抽よび高品位のホウ素の回収が見込 まれる吸脱着処理システムの開発を目的として，カチオン系 高分子ポリアリルアミンにD(t)ママンノースなどの糖類を導入し た䌅型ポリアリルアミン吸着材の合成法を明らかにすると共 に，得られた吸着材のホウ素吸着特性について検討した。

ジメチルアミンボランを還元㑉とする還元的アルキル化反 応によるD(t)-マンノース型ポリアリルアミンの合成条件を調べ た結果，ポリアリルアミンに対する什ママンノ一ス拈よびジメチ ルアミンボランの最適添加量はいずれも母材1単位に対して 等モル量であった。最適反応時間および同反応温度は各々

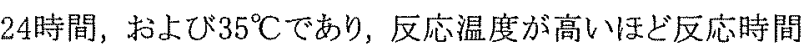
が短縮できる傾向にあった。
バッチ法によるホウ素吸着特性を調べた結果，吸着速度 は市販のメチルグルカミン系ホウ素吸着材と同等であること がわかった。吸着のpH侬存性を調べた結果，オキソ酸仏 ンとして溶存する弱酸性からpH9.5の範囲では，pHが高くな るにつれてホウ秦吸着量は增加し，pH9.5以上では急激に 低下した。最適吸着pHは8.5付近と考えられた。ホウ素の最

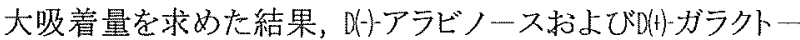
ス型ポリアリルアミンのホウ菜吸着量が最も高く，叶ママンノー ス型ポリアリルアミンのホウ菜吸着量は最大 $2.06 \mathrm{mmol} \cdot \mathrm{g}^{-1}-\mathrm{dr}$ yであった。叶-マンノース型ポリアリルアミンによるホウ素の動 的吸着特性を明らかにするため，力ラム吸着実験を行って 破過曲線を求めた結果，破過点はメチルグルカミン系ホウ 素吸着材より約3.3倍高い值が得られた。吸着したホウ素は $1.0 \sim 0.1 \mathrm{~mol} \cdot l^{-1}$ の希塩酸により容易に溶離し，濃縮比は最 高275倍に達した。

（原稿受付 2002 年 1 月 7 日) (原稿受理 2002 年 6 月 26 日)

\section{禞 考 文 䘞}

1 ) Harada, S. and Hasegawa, S. (1984) Homopolymerization of monoallylammonium salts with azo-initiators, Makromol., Chem., Rapid Commmun., 5, 27-31.

2 ) 榙本武雄，上田敏夫，向井隆一，長谷川作郎，原田亭 (1984) ポア リルアミンの二,三の誘遵体の合成, Polymer Preprints, Japan, 33 (2), 310 .

3)上田敏夫, 任藤良典, 原田学 (1988) 特許庁, 特公昭 63-29881.

4)田中由紀，井上勝利（1996）EDTA及びDTPAの官能基老修飾し たポリアリルアミンによる金属の吸着，分析化学討諭会，第 57 回, pp.178.

5) 甲斐田泰彦，犬養吉成，安田誠二(1999) Polyallylamine (PAA) 拉上 び粕型PAAによる半金属吸着，水鼠境学会第 33 回年会，pp.200，

6 ) 早川智 (2001) 排水中のほう素回収リサイクルシステム，表面 技術捥会，めっき部会 8 月例会，pp.1-9.

7 )安田羬二，山内榑利（1987）キレート樹脂による天然ガス付随 水からの木ウ素の回収，日本化学会誌，(4)，752-756.

8)安田誠二，犬琵吉成，大庭英澍（1993）プロパンジオール系キレ 一ト檄脂によるホウ案, ゲルマニウム(IV)及びテルル(VI) の昅着 特性, 分析化学, 42, 713-718.

9）山下武広，迎勝也，境正志，甲斐田泰彦，犬资吉成，安田誠二 (2000) ポリアリルアミン (PAA) 䊒䤮誘遒体の有害半金属の吸着 特性，日本化学会第 78 回年会，pp.161.

10) Inukai, Y., Kaida, Y. and Yasuda, S. (1997) Adsorption behavior Germanium(IV) on branched-saccharide Chitosan derivatives, Analytical Sciences, 13, 221-224.

11) Ooi, K., Kanoh, H., Sonoda, A. and Hirotsu,T. (1996) Screening of adsorption for boron in brine. J. of lon Exchange, 7(3), 2-9.

12) Mtsumoto,M., Matsui, T. and Kondo, K. (1999) Adsorption mechanism of Boric acid on Chitosan resin modified by saccharides. $J$. of Chemical Engineering of Japan, 32 (2), 190-196.

13) Antikainen, P.J., Huttunen, Eine. (1973), Comparative study on the chelation of pentose with some inorganic oxy acids. Sume. Kemistilehti $B, 46,184-190$.

14) Yoshimura, K., Miyazaki, Y., Ota, F., Matsuoka, S., and Sakashita, H. (1998) Complexation of boric acid with the N-methyl-D-glucamine group in solution and in cross-linked polymer, J. Chem. Soc., Faraday Trans, $94(5), \quad 683.689$

15）Ringbom. A (1965) 錯形成反応, pp.269, 産業図㫪, 東京 16)化学大辞典委員会 (1963) 化学大辞典, 3, pp.10, 共立出版, 東京 